\title{
Sir David Martin
}

Sir David Christie Martin, the Executive Secretary of the Royal Society, died suddenly on Thursday 16 December 1976, after nearly thirty years' service as the principal executive officer of the Society. Born on 7 October 1914 in Kirkcaldy (where he did an early morning paper round which inured him to a lifelong regimen of early rising), and starting from a local primary school he proceeded to Kirkcaldy High School and thence in 1933 to Edinburgh University. After first class honours in chemistry in 1937, he took a Ph.D. in 1939 under the supervision of J. A. V. Butler on organic compounds containing deuterium. His flair for administration had already shown itself: he was the first President of the Science Students' Union at King's Buildings, and he was much concerned in the Students' Representative Council and the Athletic Club. Originally intending to become a school (a) teacher, but having had his horizons broadened by research and by student activities, he became in September 1939 Assistant Secretary of the Royal Society of Arts, which immediately released him for service in the Research Department of the Ministry of Supply for the duration of the war.

This last experience convinced him of the contribution that science could make to human affairs, even though he noted that altruism and an ability in science were not always linked characteristics in human make-up. His success in administration brought him to the notice of senior scientists, and resulted in his appointment in 1945 as General Secretary of the Chemical Society and in 1947-at the age of 32as Assistant Secretary of the Royal Society. In 1943 he had married Jean MacGaradh Wilson; and throughout his life their home, first at Stanmore and then in the new premises of the Royal Society, was a centre of warm hospitality.

As chief executive of the Society, he found himself administering an annual Parliamentary Grant-in-aid of $£ 36,000$ and a staff of 29. Some measure of the growth of his responsibilities (whilst he was not in the least an "empire builder") may be gained from the fact that the corresponding figures at his death were about $£ 2,000,000$ and 100 . Following the Scientific Information Conference in 1948 , which he organised between scien-

\section{Sorry, for copyright reasons some images on this page may not be available online}

tists of the Commonwealth and the U.S.A., he persuaded the Royal Society in the 1950 s to become its own publisher, and he encouraged other learned societies to do likewise, a step which proved substantially to their benefit. In the years before 1957 he contributed greatly to the organisation of the International Geophysical Year, in which not only were Soviet scientists brought into co-operation, but the Antarctic Treaty was signed, recognising Antarctica as a scientific laboratory above military or commercial interests.

The years after 1957 were charged with the publication of the results of the International Geophysical Year, and with preparations for the celebration of the Society's Tercentenary in 1960. This started with a formal opening by Her Majesty The Queen before an audience of some four thousand in the Albert Hall on 19 July, which was followed by ten days of lectures and visits, including a Service with a congregation of fifteen hundred in St. Paul's Cathedral. The celebrations were a major national event, with many overseas guests who had to be looked after in a manner matching the occasion, and their success was largely due to the efforts of Martin and his relatively small staff.

For some years it had been evident that the activities of the Society were out-growing its premises in Burlington House, and the possibilities of a move were contemplated. There had been talk of a national science centre somewhere in London where all scientific societies could be brought together, but the proposal that eventually took shape was the move of the Royal Society into new premises in Cariton House Terrace. This was very largely achieved under the Presidency of Lord Florey by Martin, the move finally taking place in 1967 under the Presidency of Professor (later Lord) Blackett. In this way the Society was enabled to stay in most fitting premises in central London; and although these could not become the nucleus of a national science centre, the generous policy of the Society in making its accommodation available to other learned societies for symposia and conferences has helped to make it even more a forum of general scientific activity than it was previously.

The large post-war growth in the Society's activities coincided with Martin's appointment. It was primarily due to the greater national appreciation of the value of science and technology resulting from their effects in World War II. As the time of his appointment the number of Fellows elected annually had just been raised from 20 to 25 , and it was increased to 30 in 1965 mainly to give increased recognition to engineering and technology, and to 40 in 1975 , partly to recognise the growth of science and technology in the Commonwealth. Martin made a characteristic contribution in effecting all aspects of the expansion so smoothly that very few growing pains were encountered, and the staff that he recruited to support him have unfailingly reflected the courtesy, helpfulness and discretion of which he was a model.

In addition to the obvious landmarks in the evolution of the Royal Society in the past thirty years there have been many other new activities for which he provided enthusiastic support. Relations have been developed and maintained with a wide range of national academies overseas, including those in China, the Commonwealth, Japan, Latin America, the Middle East, the U.S.A., and the U.S.S.R. The International Council of Scientific Unions, too, owes much to Martin's support, as does the European Scientific Exchange Scheme, in which some 90 British scientists are exchanged annually with a corresponding number from the Continent; and in the 1960 s he did much to save Aldabra and promote the foundation of the Royal Society re- 
search station there. These great peaks of administration, however, convey little idea of the continuous demands made of him in running the many activities of the Society It has some 120 committees and he was Secretary of nearly all of them. He also attended many of the scientific lectures, for he always retained his interest in science for its own sake.

Ever since Babbage's celebrated attack on the Society in 1830 in his Reflections on the Decline of Science in England, the function of the Society has from time to time been questioned. I can remember Martin's chuckle when I drew his attention to the fact that his 1830 predecessor had come directly under Babbage's attack for taking a $10 \%$ commission from the keeper of the tavern in which he persuaded the Royal Society to hold its annual dinner. Martin's own quiet good humour contributed to that sense of proportion which he always maintained, both in dealing with the occasional challenges to the Society and with the idiosyncracies of some of its Fellows.

One result of Babbage's attack, incidentally, was that the British Association was formed in order to become the main forum for professional men of science, in contrast to the Society, to which laymen were of ten elected at that time. Over the years, the functions of the two bodies have tended to exchange, and one of Martin's further interests lay in the Association; he was a member of its Council almost continuously from 1959 onwards. Once again, he played a part in getting Government support for the British

\section{Leopold Ruzicka}

LEOPOLD RuZICKA, one of the greatest and most influential organic chemists, died on September 26, 1976. His work exemplifies that combination of severely disciplined empiricism wtih intellectual fantasy and imagination, which is the hallmark of first class organic chemistry. Ruzicka moreover was a unique character with a personality which was perpetually interesting and stimulating to all who knew him. His life also could teach us a lesson sorely needed in the United Kingdom-how to make an effective combination of academic and industrial efforts in research-if only those in authority would pay heed.

Ruzicka was born on September 13, 1887 , in Vukovar, a small town in Eastern Croatia where the river Drava joins the Danube. The family name is Czech, going back to his great-grandfather. Ruzicka's father, a cooper and timber merchant, died when the boy was four years old, and the family moved to the neighbouring town of Osijek,
Association, with funds that have been channelled through the Society.

His abilities were very widely drawn upon. He was a member of the Councils of the Royal Society of Arts, the Society for the Protection of Science and Learning, and the Charities Aid Foundation; and he was on the Executive Council of the CIBA Foundation. The Royal Society of Edinburgh elected him a Fellow in 1956. Since 1967 he had been Chairman of the B.B.C. Science Consultative Group, and since 1950 a Commissioner of Income Tax. His work was recognised by the award of a C.B.E. in 1960, and a Knighthood in 1970, and Honorary Degrees of D.Sc. from the University of Edinburgh and of D.C.L. from Newcastle.

But with all his public service, the Royal Society-both for itself and what he believed it could do-was his absorbing interest. It recognised the increased responsibilities of his office when it re-designated him Executive Secretary in 1962. By a Statute of 1847 he could not be a Fellow, for in a sense his post is one in which the holder has to be a man apart from any of the sectional interests that constitute the full spectrum of science: "A means for the Fellows to express their policies" as he himself put it, adding "I have tried to organise affairs so that all the decisions on scientific matters are taken by the Fellows." To him, his part lay in securing all the information that they needed before taking a decision, and in smoothly implementing the decision once it was taken. He was careful not to volunteer guidance but members of Council, and

many of its committee chairmen, gratefully found that he always had something helpful to say when he was asked for his opinion.

Although he could not be a Fellow, few Fellows have done more or had greater influence for good in the Society since World War II than David Martin. With his fervent belief in its cause, his valedictory words are a message for the future: "As the years have passed I have become more and more convinced that it is not enough to leave the advancement of science to scientists alone. The need to see it as making a contribution, and only one contribution, to the world's problems has caused me to recognise the desirability of seeking liaison with other bodies. . . . These bodies operate in different or wider canvasses and, in my belief, operate better in liaison with the scientific activities which the Royal Society represents. The ivory tower concept for scientists is now anachronistic and although I feel an elitist organisation for science has a vital and important role, the base of the pyramid of excellence must reside in the ordinary everyday life of the people."

As for a personal appreciation, what he said of Harold Hartley on the latter's 90th birthday might well have been said of himself: "I would not dissent from a eulogy that ascribed to him the philosophical powers of a Socrates, the strength of a Hercules and the decisive action of a Churchill, but above all he has a warm humanity, which secures a place of affection in the hearts of all those privileged to know him as a friend."

$R$. V. Jones

where the young Leopold attended the classical high school, learning much Latin and Greek but neither chemistry nor geometry. At an early age Ruzicka was determined to become a priest, but this ambition had to be abandoned and, after much thought, he decided that his life's work should be in the organic chemistry of natural products. The circumstances which influenced this decision, remarkable at such an early age, are obscure; but we have Ruzicka's own word for it.

At the age of 18 Ruzicka left the Austro-Hungarian domain and sought training in Switzerland or Germany. His first aim was to enter the Polytechnic in Zürich, but the entrance examination was forbidding in its requirement for geometry as well as chemistry. So Leopold went to the Technische Hochschule at Karlsruhe, where he was accepted without examinations. The choice was fortunate because he was free to select the lectures suited to his special interests, and he joined Hermann Staudinger. It is typical of Ruzicka's extraordinary energy and intellectual ability that in only four years he completed the course for both first and higher degrees, graduating in 1910 as Doctor Ingenieur. Staudinger invited his outstanding pupil to join him in investigating the then unknown constituents, poisonous to insects, of Chrysanthemum cinerariifolium, the pyrethrins now of such economic importance. And in 1912 Staudinger succeeded Richard Willstätter at the Eidgenössische Technische Hochschule, Zürich. So Ruzicka arrived eventually, without examination, at the institute which he was to serve so well for many years. In 1916 he ceased collaboration with Staudinger in order to work on his habilitation thesis, which in 1918 brought him the rank (unpaid) of Privat Dozent and in 1923 of titular Professor. His researches were in the field of alicyclic compounds, which always remained his chemical interest.

Finance was a great problem to the unpaid lecturer, and in 1921 he accepted an invitation to collaborate 